\title{
Quality assessment of Tsurang River water affected by coal mining along the Tsurangkong Range, Nagaland, India
}

\author{
Khikeya Semy ${ }^{1}$ (D) Maibam Romeo Singh ${ }^{1}$
}

Received: 8 June 2020 / Accepted: 7 June 2021 / Published online: 20 June 2021

(C) The Author(s) 2021

\begin{abstract}
Tsurang, a major river in the Mokokchung district of Nagaland, northeast India, shares great aspects of traditional importance for the Ao Naga tribes and is a part of natural commodity providing water to the agrarian community for irrigation and livestock rearing. However, various environment detrimental activities are practiced along the course of the riverbank, particularly coal mining and agriculture. The present study was conducted to examine the seasonal water quality index (WQI) of the Tsurang river from three selected sampling stations. Overall, the water quality status was rated as "Good" in winter and spring while "Poor" in summer and autumn. In all the seasons, downstream (S3) located at the human settlement area presented higher WQI values compared to upstream (S1) and midstream (S2). The parameters such as turbidity, DO and BOD played a central role in affecting the WQI; although, no such significant roles in case of nutrient elements were observed in affecting the water quality. The WQI revealed that Tsurang river water is deteriorated due to coal mining and other anthropogenic activities practiced along the stretch of the river and the water needs to be pretreated before consumption. Therefore, proper management strategies and conservation efforts should be enforced and regulated by policymakers to protect the river from further contamination.
\end{abstract}

Keywords Coal mines $\cdot$ Water quality parameters $\cdot$ Water quality index $\cdot$ Seasonal values

\section{Introduction}

Water plays a crucial role in sustaining livelihood and maintaining various sectors of the economy both in the urban and rural areas. The sources of freshwater include lakes, rivers, streams, ponds and rivulets. The water quality of a river has considerable importance for the reason that these water resources are generally used for multiple purposes such as residential water supplies, agriculture (irrigation), hydroelectric power plants, infrastructure, tourism, recreation, and other suitable means of using water (Venkatramanan et al. 2014). However, pollution of water sources derived from various anthropogenic activities has drastically increased over the years resulting in a shortage of potable water in different regions of the world.

Various studies by workers such as Tiwary (2000), Singh et al. (2012), Tambekar et al. (2012), Nigam et al.

Khikeya Semy

khikeyasemy@gmail.com

1 Centre for Biodiversity Study, Department of Botany, Nagaland University, Lumami 798627, India
(2015) and Sahoo et al. (2016) have indicated the deterioration effect of water due to coal mining activities. In the present scenario of development, coal mining is considered progressive to economic gains but proof detrimental of being environmental unfriendly. Starting from excavation to loading and unloading, coal produces dust and radiation which have a direct negative impact on the ecology, biodiversity and health of the surrounding communities (Chaulya et al. 2011) due to its land-use pattern creating havoc. As such altering landscape deteriorates water quality as they influence the flows of energy and material between the terrestrial and aquatic interface (Fausch et al. 2010). Water pollution caused by disposal of wastewater is one of several environmental issues associated with coal mining (Tiwary 2000), it cripples rejuvenating properties of the water. Active mining activities cause rampant pollution to both surface and groundwater at an extreme rate. During the initial period, the release of obnoxious substances such as ash, oil, phosphorus, ammonia, urea and acids affects the surface water quality of the mining regions (Reza and Singh 2010). In the long run, contamination of water through acid mine drainage is the cause

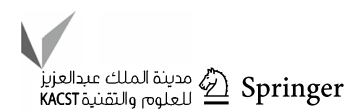


of low $\mathrm{pH}$ which creates hazardous conditions for aquatic organisms (Swer and Singh 2004). Eventually, different forms of waste are produced in mining process, which can cause various types of pollution and then ultimately render poor water quality. Moreover, anthropogenic activities like disposal of domestic sewages, runoffs from agricultural fields, unregularized public law on maintaining rivers can be contributing agents in deteriorating water quality (Yisa and Imoh 2010; Shah and Joshi 2017). The physical, chemical and biological parameters of water from any specific area or source may be assessed to check the quality and are categorized fit or unfit for human usage and other agricultural activities supported by well-defined limits (BIS 2003; ICMR 1975). Accordingly, the water quality index (WQI) is presented in terms of its suitability. Considering the importance of water in the present scenario, water quality evaluation is presented as critical issue, especially when freshwater will become a scarce resource in the future (Varol et al. 2012).

WQI determines the overall water quality at a specified time and location based on several parameters confined to result of a single number. It reduces the bulk of information from several water quality parameters into a value and expresses the data in a simplified and logical form (Semiromi et al. 2011). WQI helps to understand the water quality status of individual sampling stations at a certain time (Yogendra and Puttaiah 2008) and also facilitates comparison between different sampling sites and events (Stambuk 1999). Suitably, the category of water for its usage is considered in terms of water quality index (WQI), which in a way provides appropriate and effective means to describe water quality status. Initially, WQI was developed by Horton (1965), however, a new WQI similar to Horton's index has also been developed by Brown et al. (1970) which has undergone much improved modification. Workers like Fulazzaky (2010), Yisa and Jimoh (2010), Akoteyon et al. (2011), Chowdhury et al. (2012), Othman et al. (2012), Tyagi et al. (2013), Etim et al. (2013), Naubi et al. (2016), Ewaid (2017) and Bouslah et al. (2017) have focused on the study of WQI of different water bodies. Similarly, in India, Ramakrishnaiah et al. (2009), Chauhan and Singh (2010), Rao et al. (2010), Kumar et al. (2011), Sharma and Kansal (2011), Balan et al. (2012), Singh and Kamal (2014) and Shah and Joshi (2017) have worked on WQI of rivers in different states. WQI studies from Northeastern India, mainly confined to Assam (Singh et al. 2016), Manipur (Bora and Goswami 2017), and Nagaland (Lkr et al. 2020), have been reported. However, there is still a perceptible lack of studies using WQI to monitor seasonal water quality on rivers affected by coal mining and agricultural activities in this region. This lack of knowledge is especially evident for Nagaland, where extensive illegal coal mining and agriculture are practiced along the forested hills and river banks which has resulted in the reduction of forest cover, alteration of the landscape, loss of wildlife and degradation of potable river water.

Nagaland, a state in northeast India, is situated along the Indo-Myanmar biodiversity hotspot. Seasonal and perennial rivers including rivulets serve as water sources supporting livelihoods since time immemorial to the Nagas living in towns and villages. Tsurang river is situated at the Naga foothill bordering Assam and has a critical impact on the demarcation of ancestral land between the two states. The Tsurang literally means "Water and many things" in AOChungli dialect is an iconic river that receives considerable attention in regards to its relation with folklore, traditions, irrigations and fulfilling the demands of water shortage to the local community. However, in the last few decades', coal mining practices at Changki and the adjoining villages have drastically changed the forest landscape affecting the river and other water bodies. Large lowland river receives effluents from the coal mines and is vulnerable to different forms of anthropogenic land-use systems. These destructive phenomenons have drawn much attention to check the water quality and raise environmental concerns. Therefore, the present investigation is taken up with a view to estimate the water physicochemical properties and compute the water quality index (WQI) in order to assess the suitability of water from Tsurang river. The prime reason for using WQI in this research is to text the hypothesis whether coal mining present along the Tsurang river bank affects the status of water quality besides several pockets of land-use practices being found. The study is first of its kind at the Tsurangkong range of Mokokchung district, Nagaland and would provide us a comprehensive water quality status of the Tsurang river. The findings will reiterate measures with regulations that will also pave way robust system of river management.

\section{Materials and method}

\section{Study area}

Nagaland covers a geographical area of $16,579 \mathrm{~km}^{2}$, lies between the latitude of $25^{\circ} 06^{\prime} \mathrm{N}$ and $27^{\circ} 04^{\prime} \mathrm{N}$ and longitude of $93^{\circ} 20^{\prime} \mathrm{E}$ and $95^{\circ} 15^{\prime} \mathrm{E}$. The state is bounded by the Arunachal Pradesh and Myanmar in the east, Manipur in the south and Assam in the west and north. The state has a sub-tropical to warm temperate monsoonal climate. Rainfall varies greatly around the years and over different parts of the state, ranging from 1800 to $2500 \mathrm{~mm}$ with June, July and August receiving the highest rainfall. The Tsurang is one of the major rivers of Mokokchung district, it arises from the west of Chungliyimsen village passing through the Tsurangkong range (Naga foothills) adjoining Changki and Longtho. The river stretches $45-50 \mathrm{~km}$ till it reaches the neighboring 
state of Assam where it is named "Bhogdoi Nodi." The present study was conducted over a length of $25-30 \mathrm{~km}$. Several anthropogenic activities around the catchment area of the Tsurang river are observed. The land-use/landcover (LULC) map is shown in Fig. 1 and the features of the selected sites, their coordinates and elevation are presented in Table 1.

\section{Data collection}

Monthly water samples were collected at three stations (approximately $7 \mathrm{~km}$ apart) from Tsurang River for one year (September, 2018 to August, 2019) and later the monthly data were categorized into seasonal values covering the four seasons viz., Winter, Spring, Summer and Autumn. The glasswares utilized were pretreated by washing with dilute $\mathrm{HCl}(10 \%)$, later rinsed with distilled water and then oven dried at $50{ }^{\circ} \mathrm{C}$ in a dust-free room. Furthermore, at the sampling points, the containers were rinsed with relevant samples, filled in Tarsons bottles, corked tightly and taken to the laboratory to estimate the physicochemical parameters. The flow rate of five (5) coal mine drainage (D) entering the Tsurang river was estimated seasonally by a digital flow meter to check their inter-relation (Principal Component Analysis, OriginPro Sr1) with the water quality index (WQI).

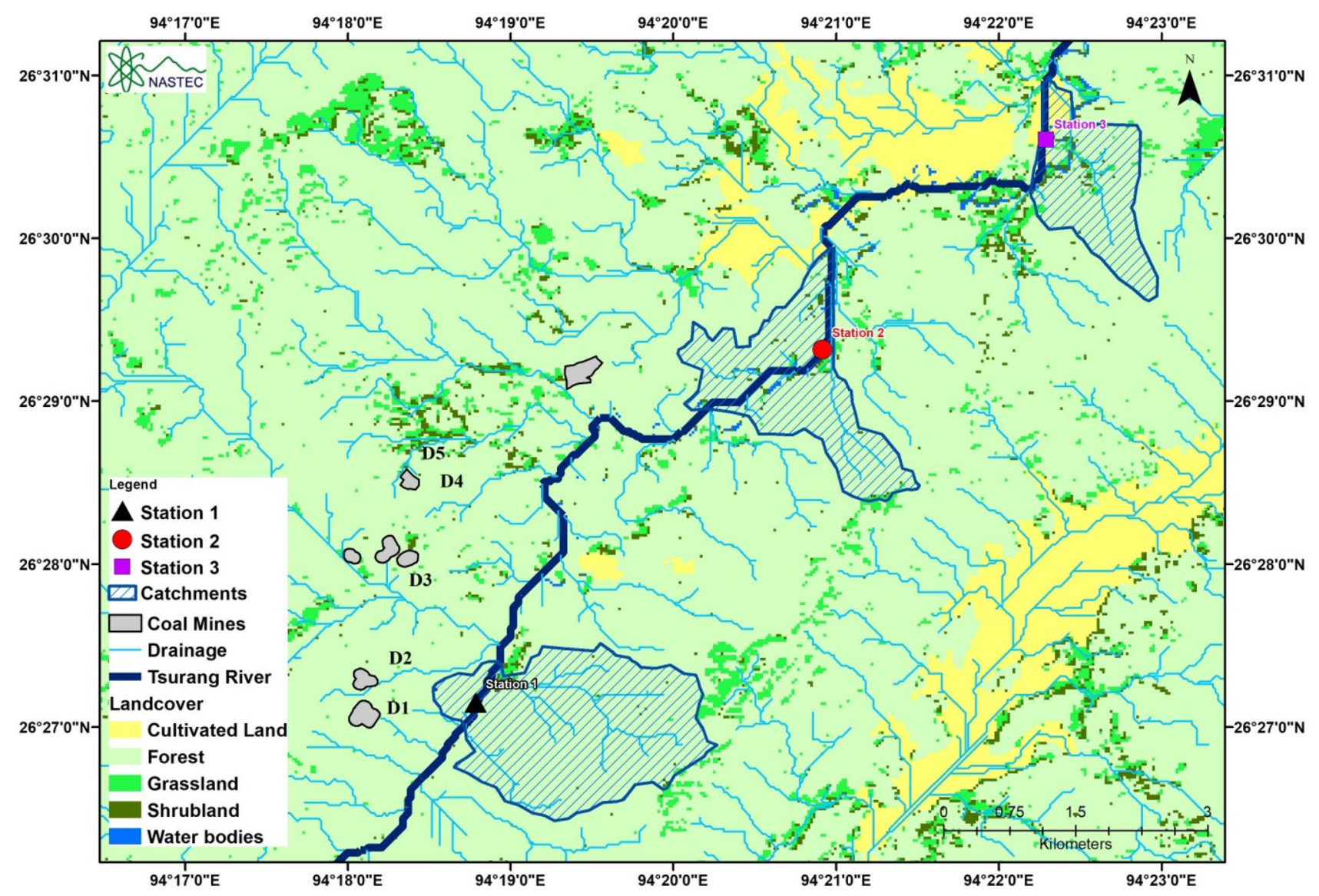

Fig. 1 Land-use and landcover map of the study area

Table 1 Characteristic features of the sampling station, their coordinates and elevation along Tsurang river

\begin{tabular}{|c|c|c|c|c|}
\hline Sampling station & Station code & Characteristics of sampling station & Coordinates & Elevation (msl) \\
\hline Station 1 & S1 & $\begin{array}{l}\text { Upstream, the station has terrain covered by semi-deciduous forest, coal mines } \\
\text { and plantations }\end{array}$ & $\begin{array}{l}26^{\circ} 27^{\prime} 09^{\prime \prime} \mathrm{N} \\
94^{\circ} 18^{\prime} 47^{\prime \prime} \mathrm{E}\end{array}$ & $199 \mathrm{~m}$ \\
\hline Station 2 & S2 & $\begin{array}{l}\text { Midstream, the landmass at this station has plantations, coal mines and sand } \\
\text { mining activities }\end{array}$ & $\begin{array}{l}26^{\circ} 29^{\prime \prime} 19^{\prime \prime} \mathrm{N} \\
94^{\circ} 20^{\prime} 55^{\prime \prime} \mathrm{E}\end{array}$ & $181 \mathrm{~m}$ \\
\hline Station 3 & S3 & $\begin{array}{l}\text { Downstream, the station is confined with agricultural fields and recreational } \\
\text { spots }\end{array}$ & $\begin{array}{l}26^{\circ} 30^{\prime} 34^{\prime \prime} \mathrm{N} \\
94^{\circ} 22^{\prime} 26^{\prime \prime} \mathrm{E}\end{array}$ & $174 \mathrm{~m}$ \\
\hline
\end{tabular}




\section{Physicochemical parameters analysis}

Thirteen (13) physicochemical parameters of water were selected for the present study, namely $\mathrm{pH}$, turbidity, electrical conductivity (EC), total dissolved solids (TDS), sulfate $\left(\mathrm{SO}_{4}{ }^{2-}\right)$, total alkalinity (TA), total hardness $(\mathrm{TH})$, chloride $\left(\mathrm{Cl}^{-}\right)$, calcium $\left(\mathrm{Ca}^{2+}\right)$, magnesium $\left(\mathrm{Mg}^{2+}\right)$, nitrate $\left(\mathrm{NO}^{3-}\right)$, dissolved oxygen (DO) and biological oxygen demand (BOD) for generating the overall WQI of Tsurang river. Physicochemical parameters such as $\mathrm{pH}$ and TDS were measured at the sampling spot using digital $\mathrm{pH}$ and TDS meter. $\mathrm{SO}_{4}{ }^{2-}$ by turbidimetric method, $\mathrm{NO}_{3}{ }^{-}$by Brucine method using double-beam UV-visible spectrophotometer, electrical conductivity (EC) using digital conductivity meter, turbidity was analyzed with the help of Nephelometer. Total alkalinity, total hardness, chloride, calcium and magnesium were analyzed by the titration method. For the measurement of dissolved oxygen, fixatives were added on the spot and analyzed thereafter using Winkler's method. Separate samples for biological oxygen demand were also collected, incubated for 5 days in the dark at $20{ }^{\circ} \mathrm{C}$ and analyzed. All the parameters were estimated following standard protocols given by Trivedi and Goel (1986) and A.P.H.A (2005). The standards given by Bureau of Indian Standard (2003) and Indian Council of Medical Research (1975) were taken into consideration to determine the permissible limit of drinking water.

\section{Water quality index (WQI) calculation}

The weighted arithmetic index (WAI) method calculates the water quality based on the degree of suitability by applying commonly measured water quality variables inferred with the aim of giving a simple numeric expression. WAI method developed by Brown et al. (1970) which has been widely used by various researchers (Chauhan and Singh 2010; Rao et al. 2010; Chowdhury et al. 2012; Balan et al 2012; Bora and Goswami 2017) to estimate the WQI is given in the following equation:

$\mathrm{WQI}=\sum Q_{n} W_{n} / \sum W_{n}$

where $Q_{n}=$ the quality rating of $n$th water quality parameter, $W_{n}=$ the unit weight of $n$th water quality parameter.

The quality rating $\left(Q_{n}\right)$ for each parameter was calculated using the following equation:

$Q_{n}=100\left[\left(V_{n}-V_{i}\right) /\left(V_{s}-V_{i}\right)\right]$

where $V_{n}=$ Estimated value of the $\mathrm{n}^{\text {th }}$ water parameters at a given sampling station, $V_{i}=$ ideal value of the parameter are taken as zero for the drinking water $\left[V_{i}=0\right.$, except for $\mathrm{pH}$ $\left(V_{i}=7\right)$ and DO $\left.\left(V_{i}=14.6 \mathrm{mg} / \mathrm{l}\right)\right], V_{s}=$ standard permissible value (BIS/ICMR) for the $n$th water quality parameter.

The index is classified to easily monitor data which involves the assigning of 'unit weight $\left(W_{n}\right)$ to estimate the WQI from the selected physicochemical parameter taken into study.

Unit weight $\left(W_{n}\right)$ was calculated using the formula

$W_{n}=k / V_{s}$

where $k=$ constant of proportionality and it is calculated using the equation

$k=\left[1 / \sum 1 / V_{s}\right]$

where $\sum\left(1 / V_{s}\right)=1 / V_{s}(\mathrm{pH})+1 / V_{s}$ (Turbidity) $+1 / V_{s}$ (Electrical Conductivity) $+1 / V_{s}$ (Total Dissolved Solids $)+1 / V_{s}$ (Total Hardness) $+1 / V_{s}$ (Total Alkalinity) $+1 / V_{s}$ (Calcium $)+1 / V_{s}$ (Magnesium $)+1 / V_{s}$ (Chloride $)+1 / V_{s}$ $($ Nitrate $)+1 / V_{s}($ Sulfate $)+1 / V_{s}($ Dissolved Oxygen $)+1 / V_{s}$ (Biological Oxygen Demand).

The WQI range and its status (Brown et al. 1972) are presented in Table 2. The weightage of all the chemical factors was calculated on the basis of this equation.

\section{Results and discussion}

\section{Physicochemical parameters}

Analytical results as presented in Table 3 revealed the physicochemical characteristics of water samples from the three sampling stations of Tsurang river. $\mathrm{pH}$ or the "potential of hydrogen" measures the concentration of hydrogen ions determining the acidity or alkalinity of the water which serves as an important indicator for water quality. The observed range of $\mathrm{pH}$ (3.3-6.19) was acidic throughout the four seasons and did not meet the standard permissible limit given by BIS/ICMR. Pyrites, the most common sulfide mineral in coal and a major source of sulfur reacts with water molecules to form sulfuric acid, which is

Table 2 Water quality index (WQI) range and status of water sample (Brown et al. 1972)

\begin{tabular}{ll}
\hline WQI range & Water quality status (WQS) \\
\hline $0-25$ & Excellent water quality \\
$26-50$ & Good water quality \\
$51-75$ & Poor water quality \\
$76-100$ & Very poor water quality \\
Above 100 & Unsuitable for drinking purpose
\end{tabular}


Table 3 Seasonal variation in water quality parameters of Tsurang river

\begin{tabular}{|c|c|c|c|c|c|c|c|c|}
\hline \multirow[t]{2}{*}{ Parameters } & \multicolumn{2}{|l|}{ Winter } & \multicolumn{2}{|l|}{ Spring } & \multicolumn{2}{|l|}{ Summer } & \multicolumn{2}{|l|}{ Autumn } \\
\hline & Range & Mean \pm SD & Range & Mean \pm SD & Range & Mean \pm SD & Range & Mean \pm SD \\
\hline $\mathrm{pH}$ & $5.1-6.6$ & $6.19 \pm 0.11$ & $5.2-6.9$ & $5.95 \pm 0.10$ & $3.3-4.9$ & $4.04 \pm 0.05$ & $3.4-4.9$ & $4.34 \pm 0.19$ \\
\hline Turbidity & $2.63-2.93$ & $2.79 \pm 0.15$ & $3.43-3.8$ & $3.6 \pm 0.19$ & $9.06-9.7$ & $9.34 \pm 0.32$ & $7.47-8.0$ & $7.74 \pm 0.26$ \\
\hline $\mathrm{EC}$ & $171-194$ & $183.64 \pm 2.86$ & $170-196.1$ & $185.67 \pm 8.24$ & $197-249$ & $218.58 \pm 11.86$ & $171-227$ & $196.48 \pm 8.79$ \\
\hline TDS & $105-156$ & $125.33 \pm 12.91$ & $107-163$ & $135.33 \pm 10.10$ & $138-177$ & $159.55 \pm 12.21$ & $143-183$ & $161.99 \pm 15.18$ \\
\hline $\mathrm{TH}$ & $108-144$ & $132.22 \pm 3.78$ & $98-132$ & $115.55 \pm 5.59$ & $80-124$ & $98.88 \pm 5.39$ & $76-100$ & $85.106 \pm 4.07$ \\
\hline TA & $175-230$ & $197.22 \pm 10.18$ & $175-215$ & $194.44 \pm 8.39$ & $130-180$ & $158.88 \pm 9.177$ & $120-155$ & $136.66 \pm 10.92$ \\
\hline $\mathrm{Ca}^{2+}$ & $48-70.04$ & $62.67 \pm 5.01$ & $35.9-70.04$ & $50.18 \pm 3.92$ & $28.02-58$ & $46.89 \pm 4.42$ & $32-58$ & $44.15 \pm 4.55$ \\
\hline $\mathrm{Mg}^{2+}$ & $12.1-18.5$ & $16.19 \pm 1.05$ & $14.6-17.1$ & $15.64 \pm 0.105$ & $10.7-16.1$ & $12.62 \pm 1.14$ & $8.7-11.2$ & $10.22 \pm 0.601$ \\
\hline $\mathrm{Cl}^{-}$ & $28.4-52$ & $38.39 \pm 4.705$ & $31.2-41.1$ & $36.86 \pm 2.63$ & $49.7-69.5$ & $59.75 \pm 4.11$ & $62-79.5$ & $70.44 \pm 4.10$ \\
\hline $\mathrm{NO}_{3}^{-}$ & $2.1-3.8$ & $2.85 \pm 0.29$ & $2.3-3.9$ & $3.12 \pm 0.31$ & $3.7-4.9$ & $4.42 \pm 0.301$ & $3.2-4.8$ & $3.98 \pm 0.22$ \\
\hline $\mathrm{SO}_{4}^{2-}$ & $158-225$ & $185.88 \pm 12.40$ & $164-220$ & $192.33 \pm 8.35$ & $253-308$ & $279.88 \pm 14.81$ & $231-286$ & $253.77 \pm 16.34$ \\
\hline DO & $6.2-9.2$ & $7.95 \pm 0.402$ & $6.0-8.0$ & $6.71 \pm 0.27$ & $4.0-5.4$ & $4.66 \pm 0.17$ & $5.6-6.8$ & $6.24 \pm 0.23$ \\
\hline BOD & $3.0-3.8$ & $3.53 \pm 0.33$ & $2.4-4$ & $3.31 \pm 0.29$ & $2-3.6$ & $2.58 \pm 0.35$ & $3-4.44$ & $3.68 \pm 0.38$ \\
\hline
\end{tabular}

All the parameters are expressed in $\mathrm{mg} / \mathrm{l}$ except for $\mathrm{pH}$, turbidity (NTU) and $\mathrm{EC}(\mu \mathrm{S} / \mathrm{cm})$

primarily responsible for the acidity of coal mining contaminated water (Swer and Singh 2004). Turbidity measures the degree of loss in water transparency caused by the presence of suspended particulates, it can be visually observed up to some extent. It was recorded beyond the permissible limit of BIS/ICMR in summer $(9.34 \pm 0.32 \mathrm{NTU})$ and autumn ( $7.74 \pm 0.26 \mathrm{NTU})$. EC varies seasonally with the highest mean value recorded in summer $(218.58 \pm 11.86$ $\mu \mathrm{S} / \mathrm{cm})$ followed by autumn $(196.48 \pm 8.79 \mu \mathrm{S} / \mathrm{cm})$, spring $(185.67 \pm 8.24 \mu \mathrm{S} / \mathrm{cm})$ and winter $(183.64 \pm 2.86 \mu \mathrm{S} / \mathrm{cm})$. The average value of TDS in winter $(125.33 \pm 12.91 \mathrm{mg} / \mathrm{l})$, spring $(135.33 \pm 10.10 \mathrm{mg} / \mathrm{l})$, summer $(159.55 \pm 12.21 \mathrm{mg} / \mathrm{l})$ and autumn $(161.99 \pm 15.18 \mathrm{mg} / \mathrm{l})$ was in the standard permissible limit (BIS/ICMR). The rainy seasons bring runoff waste into the river; these include colloidal substances, dissolved solids, trace metals, salts of various chemicals and ions which increases EC, turbidity and TDS as well. The average value of calcium $(62.67 \pm 5.01 \mathrm{mg} / \mathrm{l})$, magnesium $(16.19 \pm 1.05 \mathrm{mg} / \mathrm{l})$ and total hardness $(132.22 \pm 3.78 \mathrm{mg} / \mathrm{l})$ in the river water during winter is all correlated and can be attributed due to surface runoff from limestone deposits, weathering of rocks and domestic sewages as reported by Radhakrishnan et al. (2007). Total alkalinity during the dry winter season recorded the highest average value of $197.22 \pm 10.18 \mathrm{mg} / \mathrm{l}$ ranging from $175-230 \mathrm{mg} / \mathrm{l}$ and the value decreases in the rainy seasons of summer $(158.88 \pm 9.177 \mathrm{mg} / \mathrm{l})$ and autumn $(136.66 \pm 10.92 \mathrm{mg} / \mathrm{l})$. Chloride is a common and naturally occurring element present in most natural waters and in some cases is formed from runoffs of inorganic fertilizers. An average value of $36.86 \pm 2.63 \mathrm{mg} / \mathrm{l}, 38.39 \pm 4.705 \mathrm{mg} / \mathrm{l}, 59.75 \pm 4.11 \mathrm{mg} / \mathrm{l}$ and $70.44 \pm 4.10 \mathrm{mg} / \mathrm{l}$ was recorded in spring, winter, summer and autumn respectively. There was a significant increase in chloride in the post-monsoon or autumn season. This may be attributed due to mixing of sewages and domestic waste in river water (Singh and Shrivastava 2015). Seasonally, the value of nitrate in winter $(2.85 \pm 0.29 \mathrm{mg} / \mathrm{l})$, spring $(3.12 \pm 0.31 \mathrm{mg} / \mathrm{l})$, summer $(4.42 \pm 0.301 \mathrm{mg} / \mathrm{l})$ and autumn $(3.98 \pm 0.22 \mathrm{mg} / \mathrm{l})$ was all within the permissible limit of BIS/ICMR. Meanwhile, the increase of nitrate in summer may be due to influx of nitrogen-rich floodwater or contaminated sewages from agricultural fields. The recorded mean value of sulfate in winter $(185.88 \pm 12.40 \mathrm{mg} / \mathrm{l})$, spring $(192.33 \pm 8.35 \mathrm{mg} / \mathrm{l})$, summer $(279.88 \pm 14.81 \mathrm{mg} / \mathrm{l})$ and autumn $(253.77 \pm 16.34 \mathrm{mg} / \mathrm{l})$ was relatively high in concentration and crossed the permissible limit of $150 \mathrm{mg} / \mathrm{l}$ (BIS/ICMR). The high concentration of sulfates is mainly due to the presence of iron sulfide in coal and rocks and its reaction with water and oxygen (Swer and Sing 2004), as the pyrite wastes from coal waste are chemically broken down, ions of sulfate are introduced in runoff water which flows into the river. The mean value of DO content in the water sample was found to vary from $4.66 \pm 0.17 \mathrm{mg} / \mathrm{l}$ (summer) to $7.95 \pm 0.402 \mathrm{mg} / \mathrm{l}$ (winter). High temperature in addition to sewage and other waste might be responsible for the low value of DO (Verma et al. 2012) in summer. BOD was observed highest in autumn $(3.68 \pm 0.38 \mathrm{mg} / \mathrm{l})$ followed by winter $(3.53 \pm 0.33 \mathrm{mg} / \mathrm{l})$, spring $(3.31 \pm 0.29 \mathrm{mg} / \mathrm{l})$ and summer $(2.58 \pm 0.35 \mathrm{mg} / \mathrm{l})$. The concentration of BOD in the river water indicates the presence of high organic waste and microbial activities throughout the year. From the analysis examined, most of the parameters fall under the permissible drinking water limits while some few parameters in particular like $\mathrm{pH}$, turbidity and sulfates were not within the standard limit given by BIS/ICMR. 
Table 4 Unit weights $\left(W_{n}\right)$ of the parameters and their standards to determine WQI

\begin{tabular}{|c|c|c|}
\hline Parameters & $\begin{array}{l}\text { BIS/ICMR Standards } \\
\left(V_{s}\right)\end{array}$ & Unit weight $\left(W_{n}=k / V_{s}\right)$ \\
\hline $\mathrm{pH}$ & $6.5-8.5$ & 0.14449359 \\
\hline Turbidity & 5 & 0.245639103 \\
\hline $\mathrm{EC}$ & 300 & 0.004093985 \\
\hline TDS & 500 & 0.002456391 \\
\hline $\mathrm{TH}$ & 300 & 0.004093985 \\
\hline TA & 120 & 0.010234963 \\
\hline $\mathrm{Ca}^{2+}$ & 75 & 0.01637594 \\
\hline $\mathrm{Mg}^{2+}$ & 30 & 0.040939851 \\
\hline $\mathrm{Cl}^{-}$ & 250 & 0.004912782 \\
\hline $\mathrm{NO}_{3}^{-}$ & 45 & 0.027293234 \\
\hline $\mathrm{SO}_{4}^{2-}$ & 150 & 0.00818797 \\
\hline DO & 5 & 0.245639103 \\
\hline BOD & 5 & 0.245639103 \\
\hline$\sum W_{n}=1.00$ & & \\
\hline
\end{tabular}

\section{Water quality and the seasonal flow rate of coal mine drainages}

The drinking water quality standards (BIS/ICMR) for each parameter and the unit weights assigned for the calculation of WQI are shown in Table 4. The characteristics unit weight value of each factor has significant importance on impacting the result of WQI and maximum weightage of 0.24 was assigned to turbidity, DO and BOD. Tables 5, 6 and 7 present the values observed for each selected seasonal physicochemical parameters from the three sampling stations and their corresponding WQI. WQI was recorded maximum in monsoon summer seasons with the highest value in S3 (63.77) followed by S2 (61.66) and S1 (58.81). Similar observation was made by Sahoo et al. (2016) during the monsoon and post-monsoon period at Talcher river. On the other hand, winter experienced the minimum WQI with the lowest value in S1 (44.4) followed by S2 (45.19) and S3 (45.68). The WQI of autumn at the three stations is recorded as: S1 (53.08), S2 (57.9) and S3 (59.03). Spring observed a WQI of 49.78 at S1, 49.86 at S2 and 50.99 at S3. The examined WQI points out that winter and spring have good water quality, while summer and autumn are categorized as having poor water quality (Fig. 2).

The periodic rainfall of the study area is highest during the summer and autumn seasons which covers the monsoon and post-monsoon period of the year and decreases with the arrival of dry winter months. Thus, the average flow rate of the drainages was recorded maximum in summer $\left(4.89 \pm 0.35 \mathrm{~m}^{3} / \mathrm{s}\right)$ followed by autumn $\left(3.84 \pm 0.41 \mathrm{~m}^{3} / \mathrm{s}\right)$, spring $\left(2.87 \pm 0.36 \mathrm{~m}^{3} / \mathrm{s}\right)$ and winter $\left(2.24 \pm 0.45 \mathrm{~m}^{3} / \mathrm{s}\right)$ (Table 8 ). The PCA biplot of Fig. 3 represents a strong

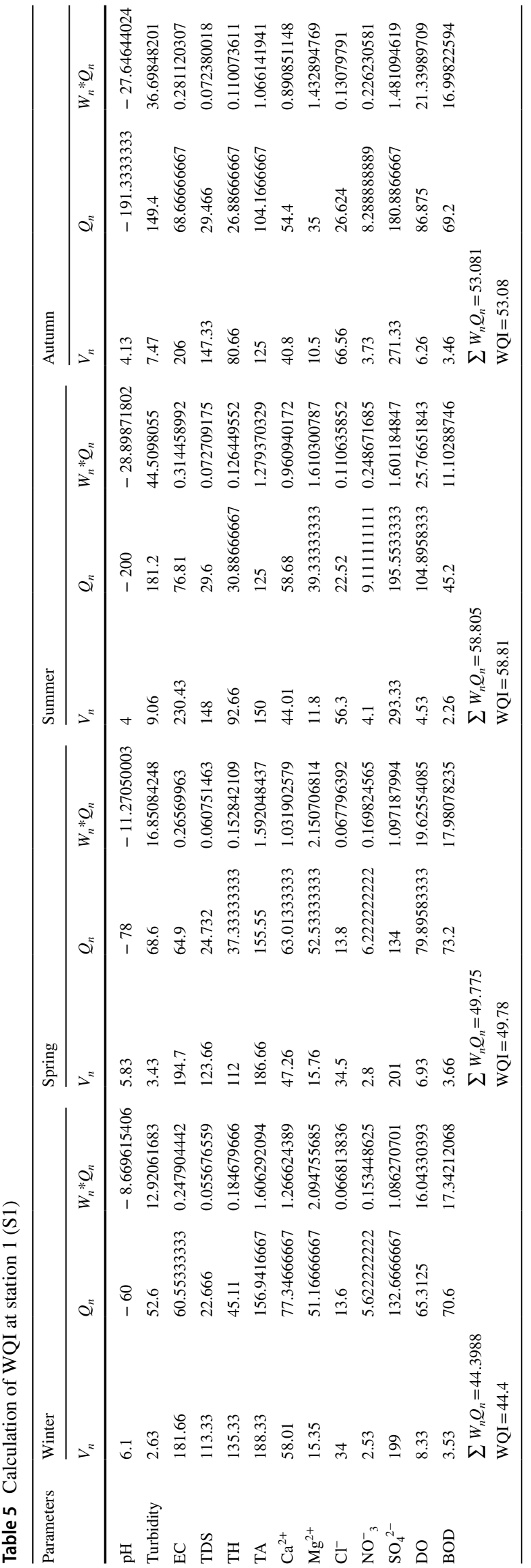



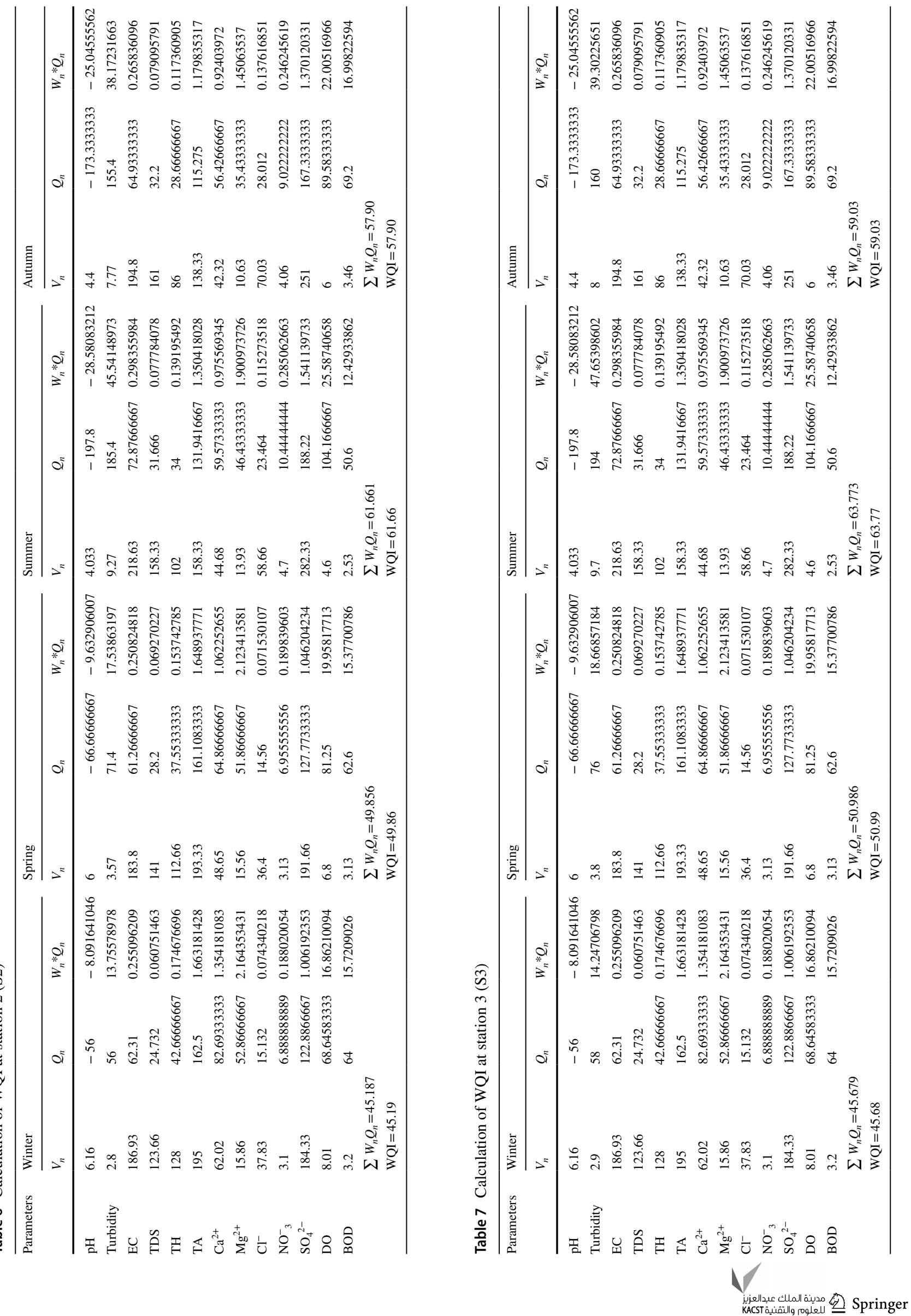


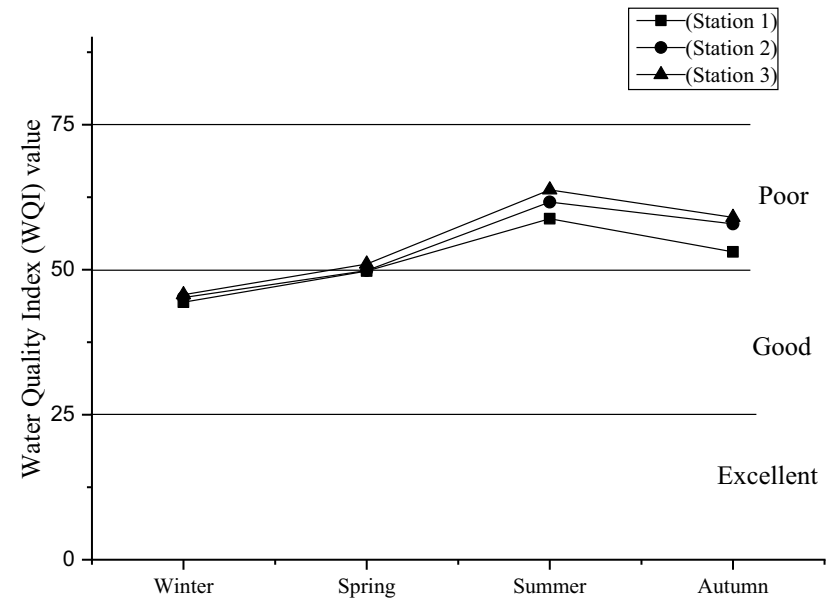

Fig. 2 Seasonal water quality status of Tsurang river

inter-relation of the flow rate of drainage (D) with the WQI of summer. The overall WQI has a high significant positive correlation with the flow rate of D1 $(p=0.97)$, D2 $(p=0.98), \mathrm{D} 3(p=0.99), \mathrm{D} 4(p=0.98)$ and D5 $(p=0.98)$. The seasonal flow rate can be categorized as summer $>$ autumn $>$ spring $>$ winter which corresponds to the WQI value. As shown is Fig. 4, with the increase of drainages flow rate in summer, the WQI also increases. The high correlation of the seasonal flow rate of mine drainages and the WQI value clearly indicates that Tsurang river water characteristics and the water quality is getting adversely affected by coal mine drainages which are in conformity with the work of Lamare and Singh (2016) on their water quality study of Lukha River, Meghalaya. However, the deterioration of water quality can be also be associated with the runoffs from different land-use practices (Paliwal et al. 2007) along the course of the river bank. As observed in the study, the trends of river water pollution increase as it flows from upstream (S1) to midstream (S2) and then to downstream (S3). This is due to the accumulation of waste from the upstream to the downstream such as pyrites from runoff coal mine drainages, forest litters, inorganic fertilizers from agricultural waste and domestic sewages from human settlement areas. Apart from coal mining, different land-use pattern located at the adjoining areas of S1 (plantations), S2 (sand mining) and S3 (agriculture and human settlements)

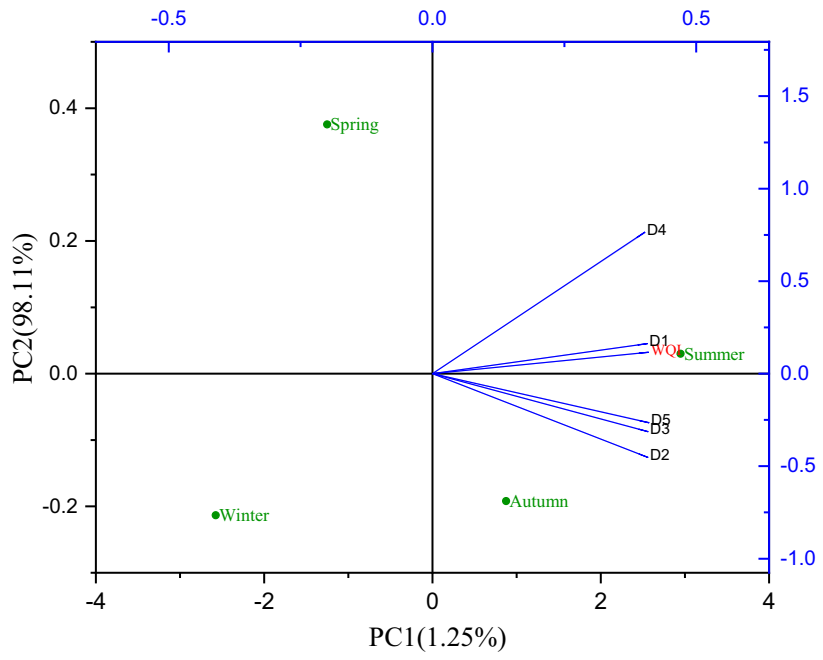

Fig. 3 PCA — biplot for the flow rate of drainages and WQI

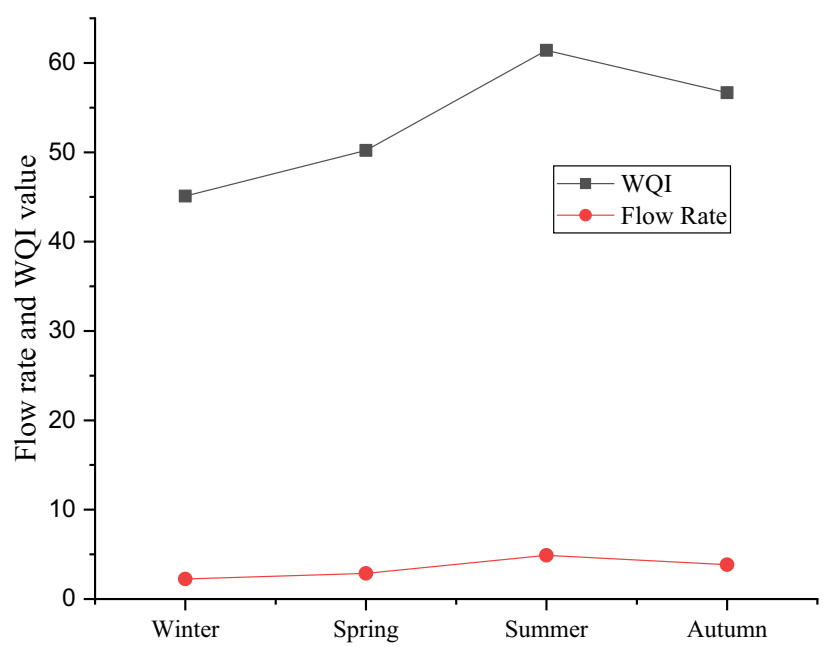

Fig. 4 Seasonal flow rate of drainages and the WQI

has played a vital role in the water chemistry influencing the physicochemical parameters in which they have exerted much pressure on the quality of water. Comparatively S3 at all seasons contributed the highest WQI as it is situated near the state highway of Nagaland (Mokokchung) to Assam (Mariani) with human settlements, it is more prone to water pollution. It can also be stated that due to the deterioration
Table 8 Seasonal flow rate of coal mine drainages

\begin{tabular}{lllllll}
\hline Seasons & D1 & D2 & D3 & D4 & D5 & Mean \pm SD \\
\hline Winter & $1.99 \pm 0.09$ & $2.24 \pm 0.04$ & $2.28 \pm 0.02$ & $1.73 \pm 0.01$ & $2.95 \pm 0.03$ & $2.24 \pm 0.45$ \\
Spring & $2.59 \pm 0.03$ & $2.49 \pm 0.02$ & $2.8 \pm 0.02$ & $3.12 \pm 0.02$ & $3.34 \pm 0.02$ & $2.87 \pm 0.36$ \\
Summer & $4.8 \pm 0.02$ & $4.45 \pm 0.02$ & $4.76 \pm 0.04$ & $5.07 \pm 0.04$ & $5.36 \pm 0.03$ & $4.89 \pm 0.35$ \\
Autumn & $3.38 \pm 0.02$ & $3.6 \pm 0.01$ & $4.09 \pm 0.01$ & $3.73 \pm 0.04$ & $4.43 \pm 0.02$ & $3.84 \pm 0.41$ \\
\hline
\end{tabular}

D - drainage, all values are expressed in $\mathrm{m}^{3} / \mathrm{s}$ 
of water quality caused by human activities in the upstream areas reduces the usability of the resources for stakeholders in the downstream areas (Fulazzaky 2010). Similar observation in pollution level was made downstream by Yoon et al. (2015) in the study of upstream water resource management to address downstream pollution concerns. Polluting activities, such as the discharge of domestic, urban and other wastewaters, into the water course and the use of chemicals on agricultural land in the drainage basin are also reported by Simeonov et al. (2003) and Bouslah et al. (2017). In regards to pollution from coal mining activities, Swer and Singh (2004) and Singh et al. (2012) have reported that mine drainages alter the quality of the water bodies to the extent that could be detrimental to the survival of aquatic life in the stream and rivers, even further downstream. Researchers working on water bodies affected by coal mining activities points out that the characteristic low pH (Swer and Singh 2003; Baruah et al. 2005; Equeenuddin et al. 2010), high turbidity (Tambekar et al. 2012) and excess concentration of sulfate (Rawat and Singh 1982; Swer and Singh 2004; Khan et al. 2013; Kumar and Singh 2016; Tiwari et al. 2016 ) in the water are directly linked to coal mine waste. The present study also shows such trends of results and rectify that the runoffs and the drainages from coal mines entering the Tsurang river have its impact on the WQI.

\section{Conclusion}

(1) The application of WQI to determine the quality of water from the three stations of Tsurang river shows that winter and spring have good quality status, while the recorded WQI values of summer and autumn indicate unfit status which can be detrimental even fatal for the local population relying on the river water.

(2) As per the observation, the flow rate of drainages has a major impact on the WQI and the water pollution increases as WQI value gets higher while the probable usage decreases. Some of the physicochemical parameters of water like $\mathrm{pH}$, turbidity and sulfate were not in the standard permissible limit and this poses a serious threat for humans relying on the river water.

(3) Major sources of pollution around the catchment area of the river include anthropogenic activities such as coal mining, sand mining, agriculture and dumping of untreated domestic waste into the river. These activities, if not enforced by law, could lead to further deterioration of water quality.

(4) The results from this investigation will provide information to the public and village councils or board members and elevate ideas to tackle river water-related issues. Predictive model for technical and scientific application can be developed to counter the effects in the near future. However, an utmost necessary step is to control the discharge of coal mining effluents, domestic sewages and agricultural waste into Tsurang river.

Acknowledgements The research work is financially supported by the Council of Science and Industrial Research (CSIR), Government of India, National Eligibility Test (NET) JRF-fellowship, File No: 09/763(0012)/2017-EMR-1. UGC SAP DRS-III, New Delhi, Government of India is duly acknowledge for the financial assistance to the Department of Botany, Nagaland University.

Author's contributions The first author is a research scholar; the manuscript is based on his Ph. D work. The second author is the guide of the first author under whose supervision the research is carried out.

Funding Not applicable.

Availability of data and material The data collected is a part of the $\mathrm{Ph}$. D research work and is provided with the best of its experiments.

\section{Declarations}

Conflict of interest The authors declare that they have no conflict of interest.

Consent to participate All the authors agreed to partake on the research conducted.

Consent for publication The authors agree to publish the paper based on the research conducted.

Code availability Not applicable.

Ethics approval Not applicable

Open Access This article is licensed under a Creative Commons Attribution 4.0 International License, which permits use, sharing, adaptation, distribution and reproduction in any medium or format, as long as you give appropriate credit to the original author(s) and the source, provide a link to the Creative Commons licence, and indicate if changes were made. The images or other third party material in this article are included in the article's Creative Commons licence, unless indicated otherwise in a credit line to the material. If material is not included in the article's Creative Commons licence and your intended use is not permitted by statutory regulation or exceeds the permitted use, you will need to obtain permission directly from the copyright holder. To view a copy of this licence, visit http://creativecommons.org/licenses/by/4.0/.

\section{References}

APHA (2005) American Public Health Association, Standard Methods for the Examination of Water and Wastewater, Method 1020

Akoteyon IS, Omotaya AO, Soladoye O, Olaoye HO (2011) Determination of water quality index and suitability of urban river for municipal water supply in Lagos-Nigeria. Eur J Sci Res 54(2):263-271

Brown RM, McClelIand NI, Deininger RA, Tozer RG (1970) A water quality index-Do we dare? Water Sew Works 117(10):339-343

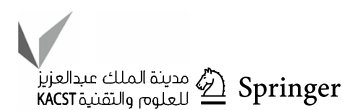


Brown RM, McClelIand NI, Deininger RA, O’Connor MF (1972) A water quality index — crashing the physiological barrier. Indic Environ Qual 1:173-182

Bureau of Indian Standards, BIS 10500 (2003) Manak Bhavan, New Delhi, India

Baruah BP, Kotoky P, Rao PG (2005) Genesis of acid mine drainage from coalfields of Assam, India. In: Proceedings of international seminar on coal science and technology-emerging global dimensions: global coal. Allied Publishers. ISBN:81-7764-818-7

Balan IN, Shivakumar M, Kumar PDM (2012) An assessment of ground water quality using water quality index in Chennai, Tamil Nadu, India. Chron Young Sci 3(2):146-150

Bora M, Goswami DC (2017) Water quality assessment in terms of water quality index (WQI): case study of the Kolong River. Appl Water Sci Assam. https://doi.org/10.1007/s13201-016-0451-y

Bouslah S, Djemili L, Houichi L (2017) Water quality index assessment of Koudiat Medouar reservoir, northeast Algeria using weighted arithmetic index method. J Water Land Dev 35(1):221-228. https://doi.org/10.1515/jwld-2017-0087

Chauhan A, Singh S (2010) Evaluation of Ganga water for drinking purpose by water quality index at Rishikesh, Uttarakhand. India Rep Opi 2(9):53-61

Chaulya SK, Kumar A, Mandal A, Tripathi N, Singh RS, Mishra PK, Bandyopadhyay LK (2011) Assessment of coal mine road dust properties for controlling air pollution. Int J Environ Prot 1(2):1-7

Chowdhury RM, Muntasir SY, Hossain MM (2012) Water quality index of water bodies along Faridpur-Barisal road in Bangladesh. Glob Eng Tech Rev 2(3):1-8

Edraki M, Golding SD, Baublys KA, Lawrence MG (2005) Hydrochemistry, mineralogy, and sulphur isotope geochemistry of acid mine drainage at the Mt. Morgan mine environment, Queensland, Australia. Appl Geochem 20:789-805

Equeenuddin SM, Tripathy S, Sahoo PK, Panigrahi MK (2010) Hydrogeochemical characteristics of acid mine drainage and water pollution at Makum Coalfield, India. J Geochem Explor 105:75-80

Etim EE, Odoh R, Itodo AU, Umoh SD, Lawal U (2013) Water quality index for the assessment of water quality from different sources in the Niger delta region of Nigeria. Front Sci 3(3):89-95. https:// doi.org/10.5923/j.fs.20130303.02

Ewaid SH (2017) Water quality evaluation of Al-Gharraf river by two water quality indices. Appl Water Sci. https://doi.org/10.1007/ s13201-016-0523-z

Fausch KD, Baxter CV, Murakami M (2010) Multiple stressors in north temperate streams: lessons from linked forest- stream ecosystems in northern Japan. Freshwater Biol 55(1):120-134

Fulazzaky MA (2010) Water quality evaluation system to assess the status and the suitability of the Citarum river water to different uses. Environ Monitor Assess 168:669-684. https://doi.org/10. 1007/s10661-009-1142-z

Horton RK (1965) An index number system for rating water quality. J Water Pollut Control Fed 37(3):300-306

I.C.M.R (1975) Manuals of standards of quality for drinking water supplies. I.C.M.R, New Delhi

Kumar RN, Solanki R, Kumar JIN (2011) An assessment of seasonal variation and water quality index of Sabarmati River and Kharicut canal at Ahmedabad, Gujarat. Elect J Environ Agri Food Chem 10(5):2248-2261

Khan I, Javed A, Khurshid S (2013) Physico-chemical analysis of surface and groundwater around Singrauli coal field, district Singrauli, Madhya Pradesh, India. Environ Earth Sci 68(7):1849-1861

Kumar A, Singh PK (2016) Qualitative assessment of mine water of the western Jharia coalfield area, Jharkhand. India Curr World Environ. https://doi.org/10.12944/CWE.11.1.37
Lamare RE, Singh OP (2016) Seasonal variation in water quality of Lukha River, Meghalaya, India. Curr World Environ 11(1):101113. https://doi.org/10.12944/CWE.11.1.14

Lkr A, Singh MR, Puro N (2020) Assessment of water quality status of Doyang River, Nagaland, India, using water quality index. Appl Water Sci 10:46. https://doi.org/10.1007/s13201-019-1133-3

Nigam GK, Sahu RK, Sinha J, Sonwanshi RN (2015) A study on physico-chemical characteristics of open cast mine water. J Indust Poll Cont 31(2):191-200

Naubi I, Zardari NH, Shirazi SM, Ibrahim NFB, Baloo L (2016) Effectiveness of water quality index for monitoring Malaysian river water quality. Pol J Environ Stud 25(1):231-239

Othman F, Eldin MEA, Mohamed I (2012) Trend analysis of a tropical urban river water quality in Malaysia. J Environ Monit Assess. https://doi.org/10.1039/c2em30676j

Paliwal R, Sharma P, Kansa A (2007) Water quality modelling of the river Yamuna (India) using QUAL2E-UNCAS. J Environ Manag 83(2):131-144. https://doi.org/10.1016/j.jenvman.2006.02.003

Rawat NS, Singh G (1982) The role of micro-organisms in the formation of acid mine drainage in the north eastern coal field of India. Int J Mine Water 2:29-36

Radhakrishnan R, Dharmaraj K, Kumari R (2007) A comparative study on the physico-chemical and bacterial analysis of drinking, borewell and sewage water in the three different places of Sivakasi. J Environ Biol 28(1):105-108

Ramakrishnaiah CR, Sadashivaiah C, Ranganna G (2009) Assessment of water quality index for the groundwater in Tumkur Taluk, Karnataka State, India. E-J Chem 6(2):523-530

Rao CS, Rao BS, Hariharan AV, Bharathi NM (2010) Determination of water quality index of some areas in Guntur district Andhra Pradesh. Int J Appl Bio Pharm Tech 1(1):79-86

Reza R, Singh G (2010) Heavy metal contamination and its indexing approach for river water. Int J Environ Sci Tech 7:785-792

Stambuk GN (1999) Water quality evaluation by an index Dalmatia. J Water Res pro 33(16):3423-3440. https://doi.org/10.1016/S00431354(99)00063-9

Simeonov V, Stratis JA, Samara C, Zachariadis G, Voutsa D, Anthemidis A (2003) Assessment of the surface water quality in Northern Greece. Water Res 37(17):4119-4124

Swer S, Singh OP (2003) Coal mining impacting water quality and aquatic biodiversity in Jaintia hills district of Meghalaya. ENVIS Bull Himal Ecol 11:26-33

Swer S, Singh OP (2004) Status of water quality in coal mining areas of Meghalaya, India. In: Proceedings of the national seminar on environmental engineering with special emphasis on mining environment; March 19-20: New Delhi, India

Semiromi FB, Hassani AH, Torabian A, Karbassi AR, Lotfi FH (2011) Water quality index development using fuzzy logic: a case study of the Karoon river of Iran. Afr J Biotech 10(50):10125-10133

Sharma D, Kansal A (2011) Water quality analysis of River Yamuna using water quality index in the national capital territory. Appl Water Sci India. https://doi.org/10.1007/s13201-011-0011-4

Singh AK, Mahato MK, Neogi B, Tewary BK, Sinha A (2012) Environmental geochemistry and quality assessment of mine water of Jharia coalfield. Environ Earth Sci 65(1):49-65

Singh G, Kamal RK (2014) Application of water quality index for assessment of surface water quality status in Goa. Curr World Environ 9(3):994-1000. https://doi.org/10.12944/CWE.9.3.54

Singh PK, Shrivastava P (2015) Analysis of water quality of river Narmada. Int J Cur Res 7(12):24073-24076

Sahoo M, Mahananda MR, Seth P (2016) Physico-chemical analysis of surface and groundwater around Talcher coal field, district Angul, Odisha, India. J Geosci Environ Prot 4:26-37

Singh RKB, Singh TC, Singh TR (2016) Assessment of Water quality index of Nambul River, Imphal, Manipur, India. IRJET 3(12):1462-1467 
Shah KA, Joshi GS (2017) Evaluation of water quality index for river Sabarmati. Appl Water Sci 7:1349-1358. https://doi.org/10.1007/ s13201-015-0318-7

Trivedy RK, Goel PK (1986) Chemical and Biological method for water pollution studies. Environ Publ 6:10-12

Tiwary RK (2000) Environmental impact of coal mining on water regime and its management. Water Air Soil Pol 1329(1):185-199

Tambekar P, Batra RJ, Weginwar RG (2012) Assesment of water quality from Hindustan Lalpeth coal mine, Chandrapur. J Chem Pharma Res 4(8):3813-3821

Tyagi S, Sharma B, Singh P, Dobhal R (2013) Water quality assessment in terms of water quality index. Amer J Water Resour 1(3):34-38

Tiwari AK, Singh PK, Mahato MK (2016) Environmental geochemistry and a quality assessment of mine water of the west Bokaro coalfield, India. Mine Water Environ 35:525-535. https://doi.org/ 10.1007/s10230-015-0382-0

Verma P, Deepika C, Urvi G, Hitesg SV (2012) Water quality analysis of an organically polluted lake by investigating different physical and chemical parameters. Int J Res Chem Environ 2(1):105-111

Varol M, Gokot B, Bekleyen A, Sen B (2012) Water quality assessment and apportionment of pollution sources of Tigris river (Turkey) using, multivariate statistical techniques - a case study. River Res App 28:1428-1438
Venkatramanan S, Chung SY, Lee SY, Park N (2014) Assessment of river water quality via environmentric multivariate statistical tools and water quality index: a case study of Nakdong River Basin, Korea. Carp J Earth Environ Sci 9(2):125-132

Yogendra K, Puttaiah ET (2008) Determination of water quality index and suitability of an urban waterbody in Shimoga town, Karnataka. In: Sengupta M, Dalwani R (Ed) Proceeding of taal 2007: the 12th world lake conference, pp 342-346

Yisa J, Jimoh T (2010) Analytical studies on water quality index of river Landzu. Am J Appl Sci 7(4):453-458

Yoon T, Rhodes C, Shah FA (2015) Upstream water resource management to address downstream pollution concerns: a policy framework with application to the Nakdong river basin in South Korea. Water Resour Res 51(2):787-805. https://doi.org/10.1002/2013W R014201

Publisher's Note Springer Nature remains neutral with regard to jurisdictional claims in published maps and institutional affiliations. 